\title{
動物の形態及運步上に於ける左右不相稱
}

右利き左利きに就ての研究.I.鳥類

\author{
松原茂平
}

(陸軍獸學礐校)

STUDIES ON THE LEFIHANDER OF ANIMALS

AS WELI AS ITS MORPHOLOGICAL

AND MOVEMENTAI, DI FFERENCE.

\section{EXPERIMENTS ON}

THE BIRDS.

M. MAtsubara.

(1.rom the rimy Ve'erintry Sehool, Tokyo)

目次

I. 緹 言

II. 鳥類の左右茈に於け万肜態上

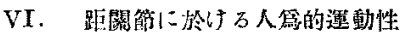
不 相 程 の不相稱

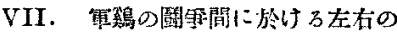

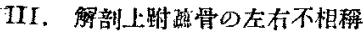
不相葐

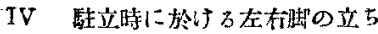
方跳閏角度

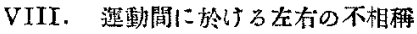

IX. 總括

V 鷑の龍骨に於け万鼠抽垃に之

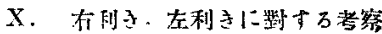
に伴ふ助管の彎形

\section{I. 緒言}

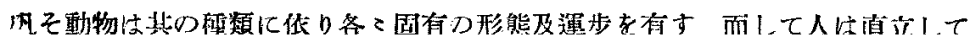




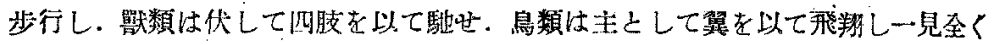

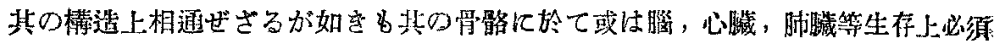

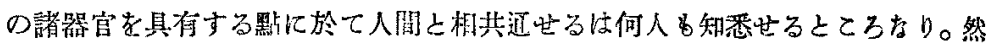

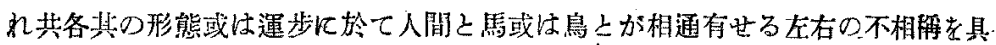
有すへしとは容易に想像し得さるとてろなるへし。古來人に就ては正規的古右の

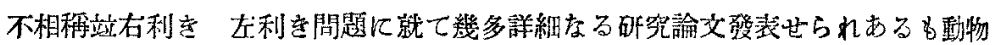

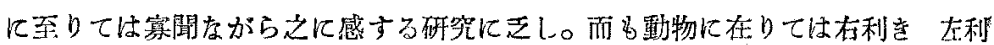

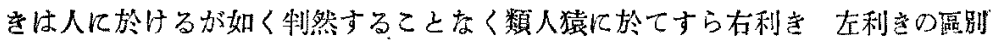

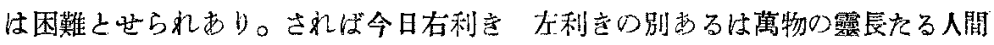

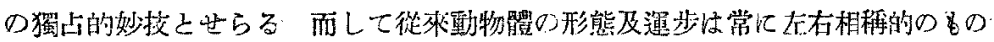

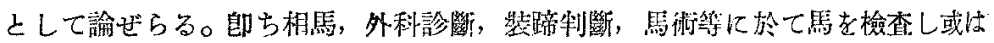

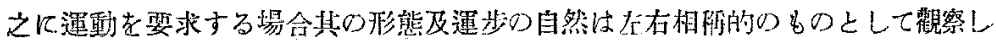
及取扱はれ放り。

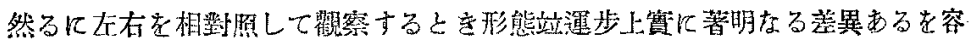

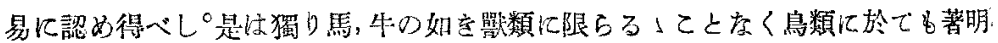
の重賽症り。

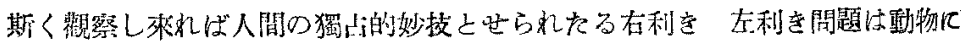

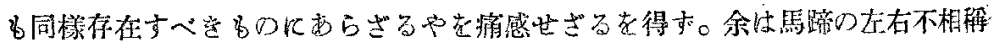

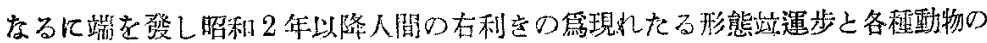

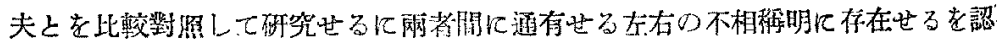

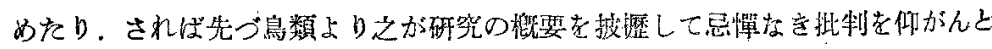

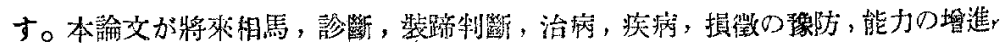

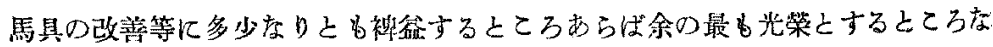
D。

\section{II. 鳥類の左古趾に於ける形態上の不相稱}

1. 踓 蹯 部

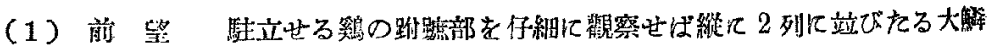

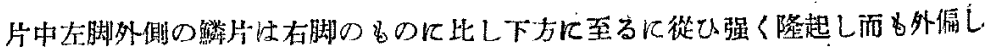




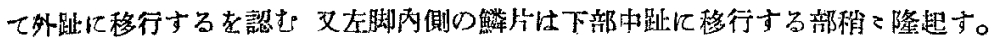

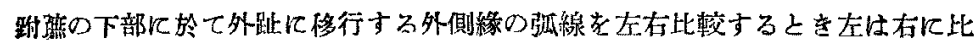
し外側緣張り出し緩傾科老以て外趾に移行世るに反し. 右は稍 2 急にして处趾に

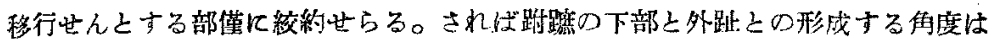
右脚仕左脚上りる小なり。(Fig. I, IV参热)

又內側上部に於て左は右よりも下部より队ト方に向儿張出し飛笁に移行せり。

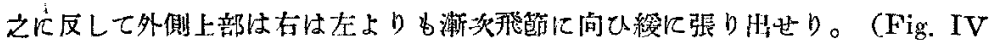
參照)

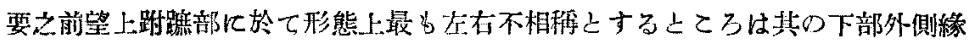

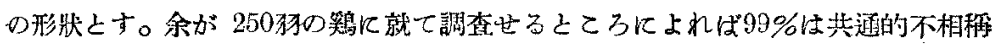

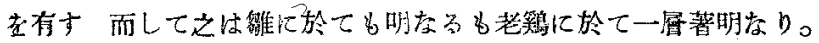

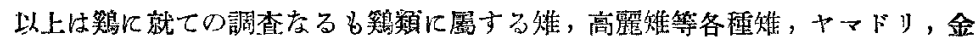

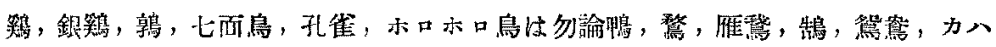

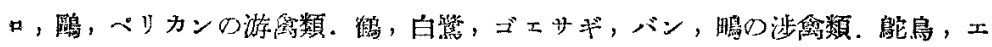

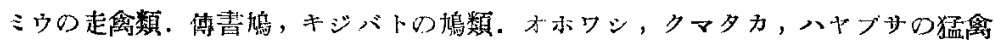

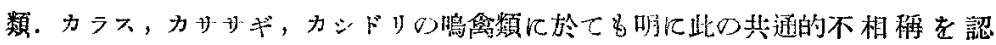
to

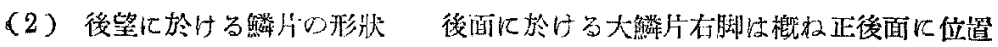

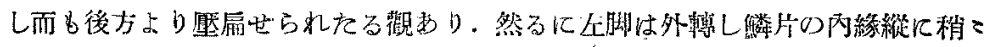

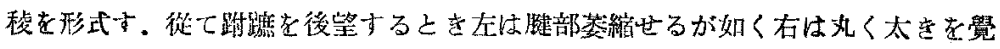

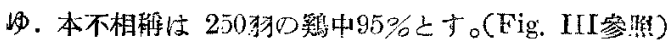

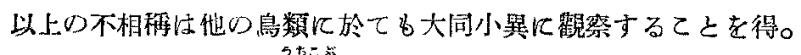

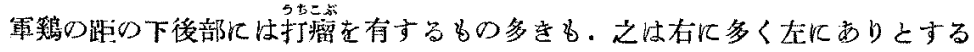

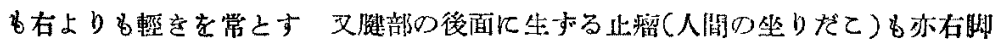
撥せるも0多し。

2. 距

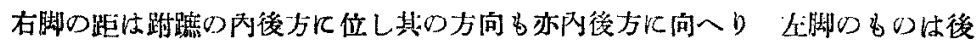

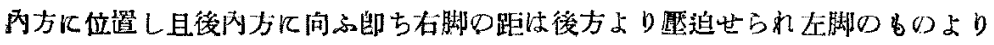
b少しく前方に位琵し且つ內万亿向へD。(Fig, I, III, IV, VIII 参照) 
刃距の太さ及で長さは左脚て於て優るもの多し，例へば踓に於て長距を有する が如を場合古のみ嬁育せるるの多し。

以上距に於ける不相稱は雉，ヤマドリ，孔隻に於て等しく認むるとと得。今

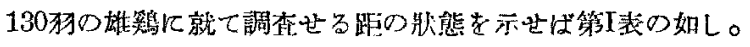

\begin{tabular}{|c|c|c|c|c|}
\hline 右别 & 方 & 位 & 太 & 長 \\
\hline 左 & $\begin{array}{l}\text { 後內方に向八る } \\
\mathrm{b} の \\
130 . \quad 100 \%\end{array}$ & $\begin{array}{l}\text { 管の後內方 } \\
130.100 \%\end{array}$ & $\begin{array}{l}\text { 太䒠 むの } \\
99.76 \% \\
\end{array}$ & $\begin{array}{l}\text { 長 } 340 \\
96 . \quad 74 \% \\
\end{array}$ \\
\hline 右 & $\begin{array}{l}\text { 內渚方に向一る } \\
6 \% \\
130.100 \%\end{array}$ & $\begin{array}{l}\text { 管の内後方 } \\
130.100 \%\end{array}$ & $\begin{array}{l}\text { } ₫ 6 \\
31.24 \% 6\end{array}$ & 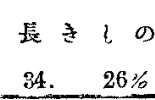 \\
\hline
\end{tabular}

\section{3. 駐立時に於ける趾の狀態}

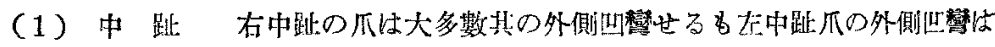

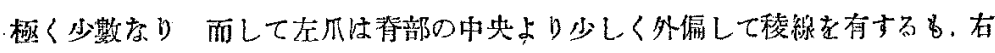
爪は此の稜線著しく外编し見しきは稜總の外䚋壁峻立せり 從てを爪は右爪より も一般に橫徑大なり。(Fig. VIII參照)。

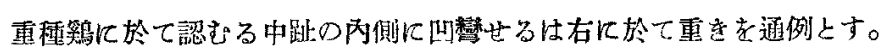

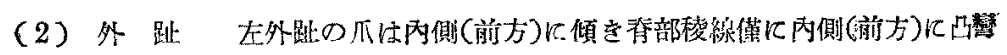

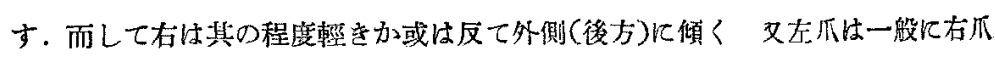
よりも幅廣し。(Fig. VIII參照)

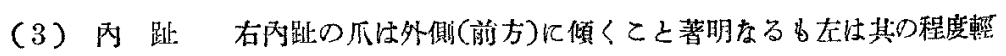

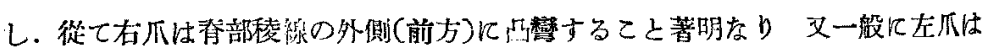
右爪よりも幅磨し。(Fig.VIII參照)

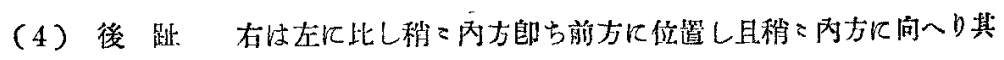

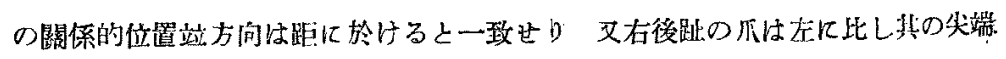
明に磨減せるむの多し。(Fig. III, VIII参溜)。

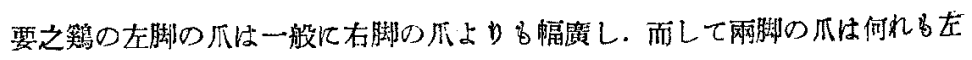

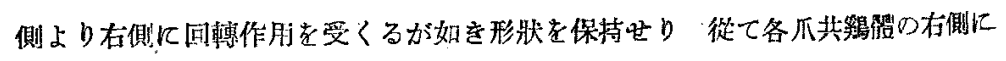




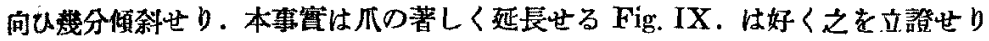

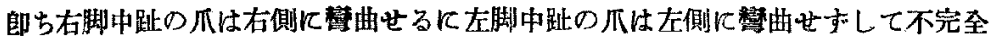

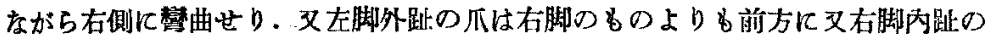
爪生左脚のもの上りも稍に多く前方儿傾けり。叉右後趾は左後趾飞比し稍こ內側

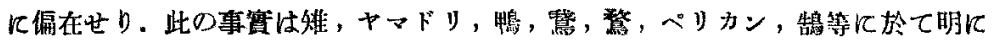
認むるととを得。

\section{4. 踾球の狀態}

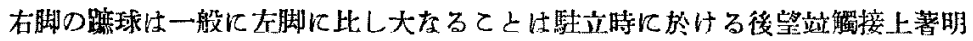

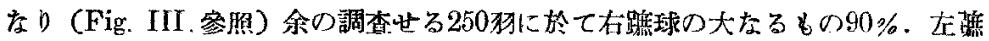
球の大存るもの $10 \%$ とす。

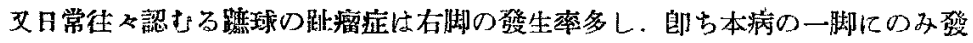

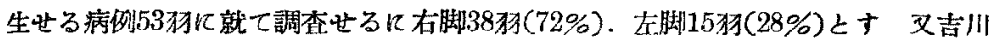

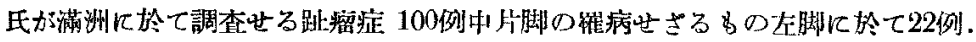
右脚飞於て15例とす。

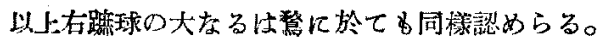

\section{5. 飛笽の牀態}

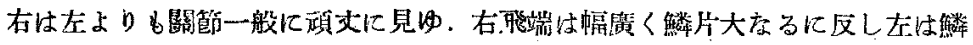
片外轉して獭小其の队側右上り必四陷す。

\section{III. 解剖上踓蹠骨の左右不相稱}

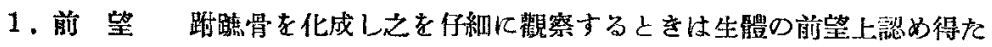

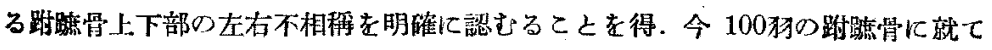
䚋察せる左右の不相稱次の如し。

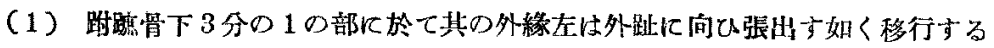

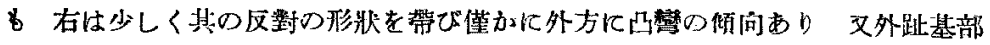
郎ち躈踦骨の下外春部左は稍

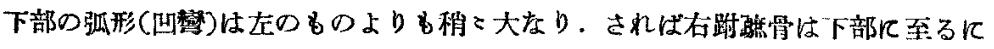

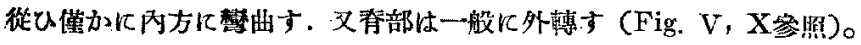

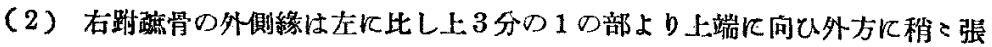




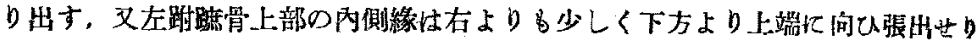
右は內㑡緣上端に近く絞約せらるれてと著明なり。(Fig. V,X急照)。

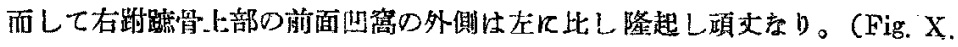
突照)。

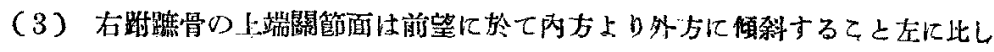

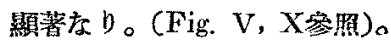

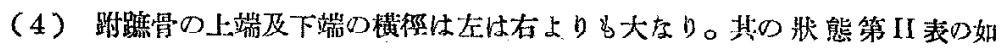
Lo

\begin{tabular}{|c|c|c|c|c|c|c|c|c|}
\hline \multirow{2}{*}{ 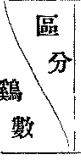 } & \multicolumn{2}{|c|}{ 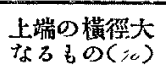 } & \multicolumn{2}{|c|}{$\begin{array}{l}\text { 上端橫㿥本均 } \\
(\mathrm{m} \cdot \mathrm{m})\end{array}$} & \multicolumn{2}{|c|}{ 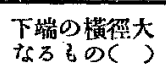 } & \multicolumn{2}{|c|}{ 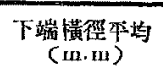 } \\
\hline & 左 & 有 & 左 & 右 & 左 & 右 & tr & 右 \\
\hline $100^{\text {新 }}$ & 72 & 14 & 14.93 & 14.75 & 60 & 12 & 14.50 & 14.29 \\
\hline
\end{tabular}

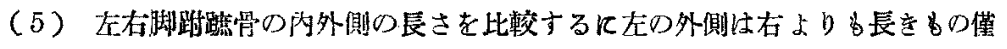

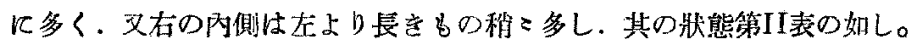

\begin{tabular}{|c|c|c|c|c|c|c|c|c|}
\hline \multirow{2}{*}{ 㑷 } & \multicolumn{2}{|c|}{$\begin{array}{c}\text { 外側の長 } \\
(\%)\end{array}$} & \multicolumn{2}{|c|}{$\begin{array}{c}\text { 外側の長さ不鸡 } \\
(\mathrm{m}, \mathrm{m})\end{array}$} & \multicolumn{2}{|c|}{ 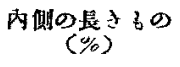 } & \multicolumn{2}{|c|}{$\begin{array}{c}\text { 冈側の長さ代均 } \\
(\mathrm{m} \cdot \mathrm{m})\end{array}$} \\
\hline & 左 & 右 & 左 & 右 & t: & 右 & 左 & 右 \\
\hline $100^{\text {炣 }}$ & 46 & 41 & 77.70 & 77.71 & 37 & 49 & 78.01 & 78.08 \\
\hline
\end{tabular}

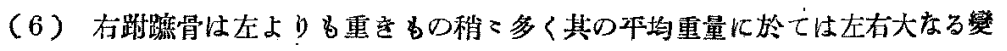
化なL，其の狀態第IV表の如L。

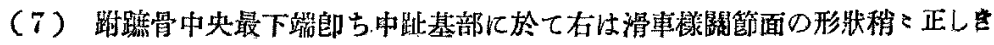

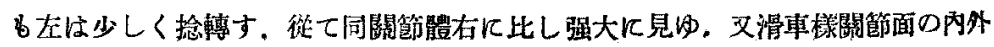

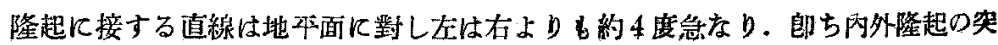




\begin{tabular}{|c|c|c|c|c|}
\hline \multirow{2}{*}{ 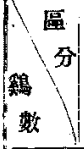 } & \multicolumn{2}{|c|}{ 跗蹨骨の重量重きしの } & 跗路骨の本均重量 & $(g)$ \\
\hline & t & 右 & 左 & 右 \\
\hline 100 駧 & 27 & 36 & $3.24_{\text {弱 }}$ & $3.24_{\text {强 }}$ \\
\hline
\end{tabular}

利の差.左估右より著明にして在脚の內隆起は右に比し萎縮せり。

次们趾及外趾の下端を連る直線が地平面と成寸角度は左は右上りる約 3.5 度 急标り。

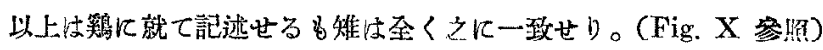

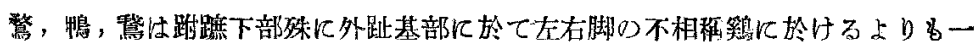

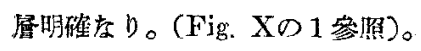

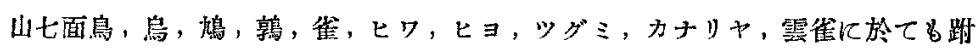

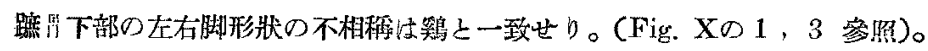

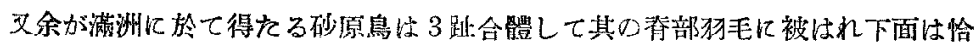
タモグラモチの足に似たり。(Fig. Xの3參照)。

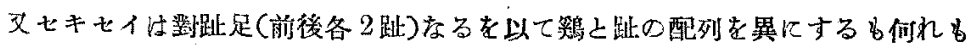

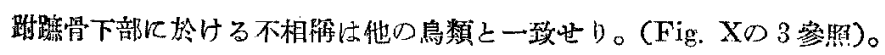

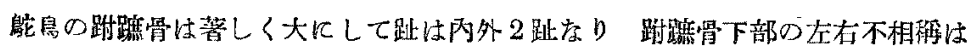

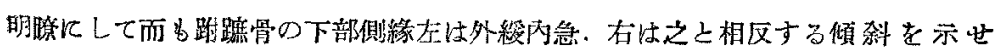
り。(Fig. $\mathrm{X} \odot 4$ 参留)。

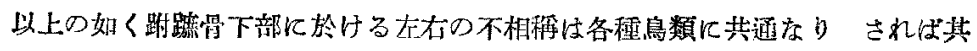
の他の生體に於て左右の不相稱を認め得をる前記鳥類の跳跐骨も亦以上の如を共 通の左右不相稃を具有すべをゃ朋白なり。

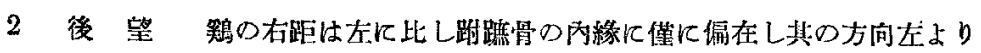

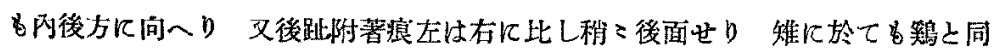
㥞なり。 


\section{IV. 駐立時に於ける左古脚の立ち方站趾間角度}

鴙は堲立時一般に右脚を春杜下に入れ之に多く負重し左脚は之より少しく外方

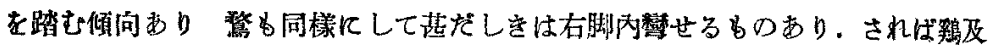

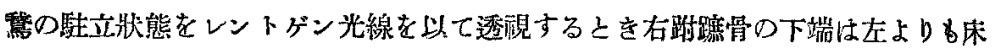
面に接近せるを認む。(Fig. V, VII参盟)。

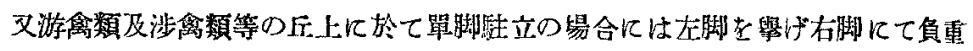
ナるもの73\%なり。

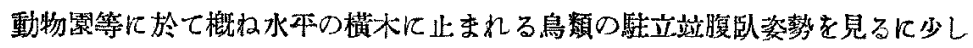

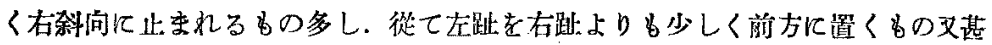
たしをは右脚の外趾を止りホの後方䈯くものあり。

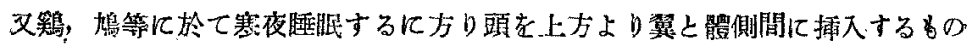
は70\%は左側㨂入とす。

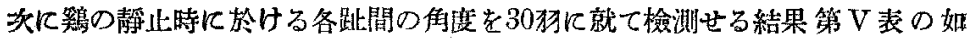
Lo

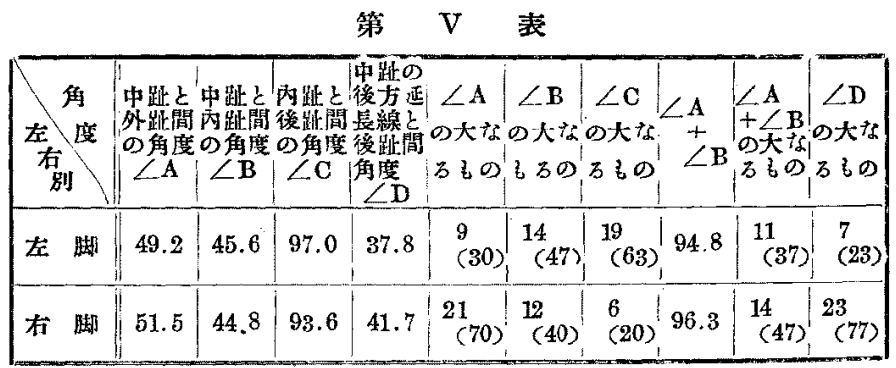

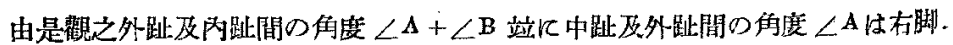

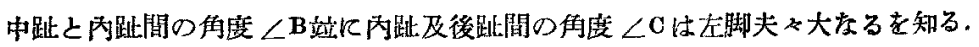

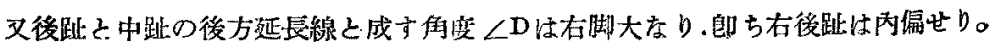

今趾間角度の狀態を示せば第I及第II圆の娕し。 
第 I 圖
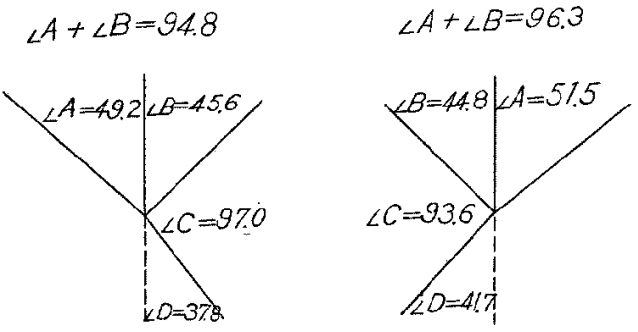

雉の趾間角度 三羽の本均とす

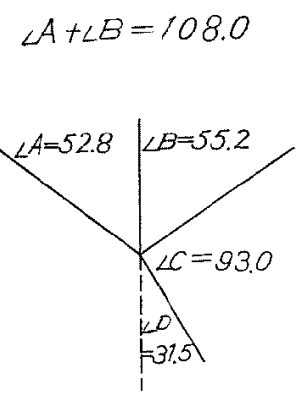

$$
\angle A+\angle B=103.2
$$

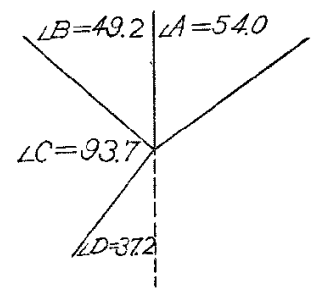

ウウズゔの趾間角度

一羽の平均と寸
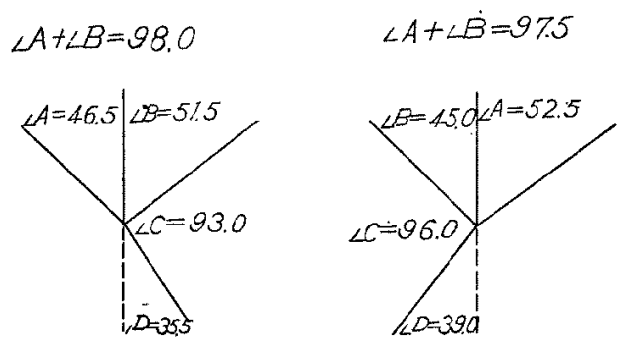


\section{第 II 圖}

翼の趾間角度 次の如认

$\angle A+\angle B=82.0$

$\angle A+\angle B=80.0$
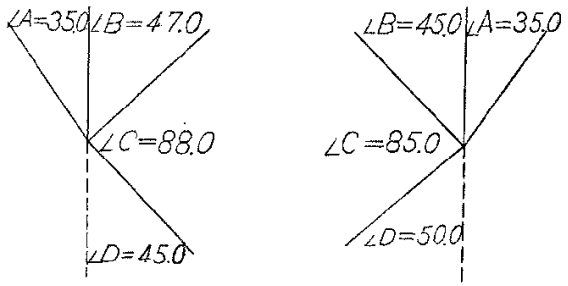

熱の趾看度 次の如i

$$
A+\angle B=680
$$

$\angle A+\angle B=68.5$
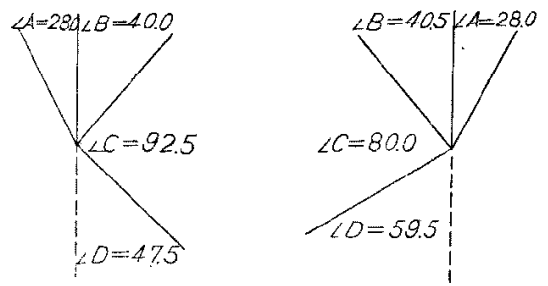

ックグミっの趾間角度 次の如に
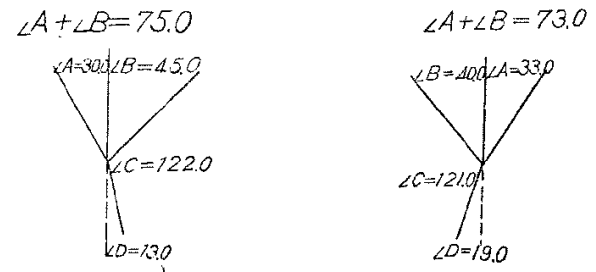


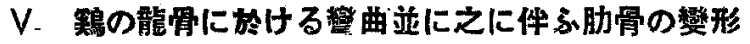

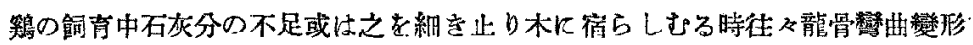

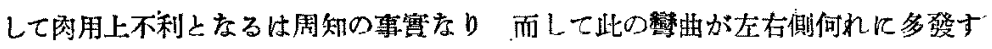

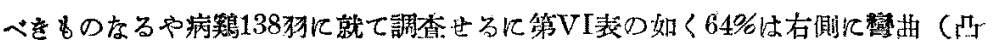
臂) せり。

\begin{tabular}{|c|c|c|c|c|}
\hline 龍骨の留曲鵎數 & 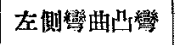 & 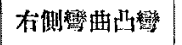 & 摘 & 要 \\
\hline 138 可 & 99 狗 $(64 \%)$ & 49 歼 $(36 \%)$ & 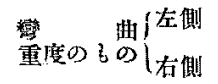 & $\begin{array}{l}12 \text { 狗 } \\
19 \text { 犽 }\end{array}$ \\
\hline
\end{tabular}

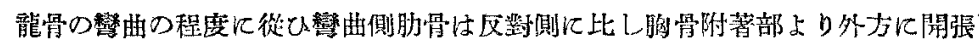

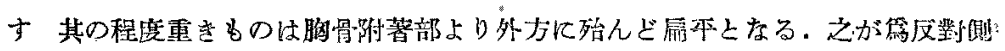

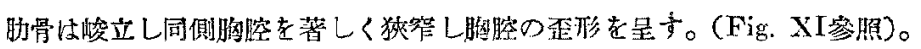

\section{VI. 距關笁に於ける人爲的運動性の不相稱}

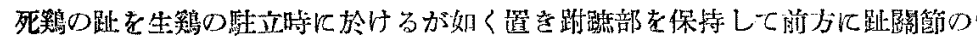

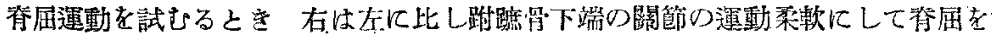

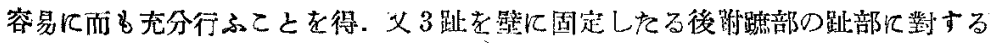
運動狀態を見るに，右は其の下端を軸として右回轉の度强し，從て中趾に對し踓

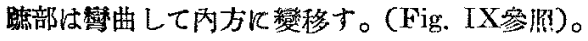

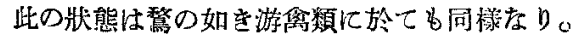

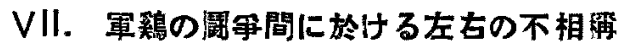

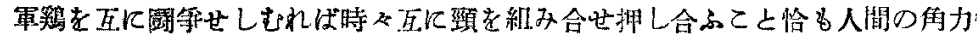

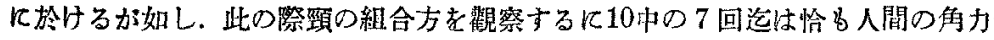

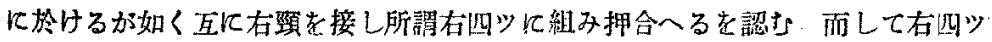
に組みをる場合と左四ツに組みたる場合とに於て何れが艘賽に踏み張り而も敵を 


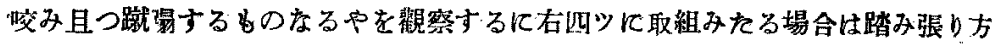

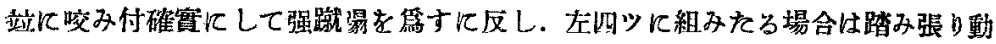

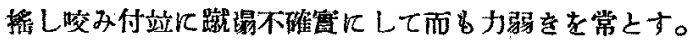

以上の場合左右何れの脚を以て多く蹴晹するるのたるやに就て研究するに、名

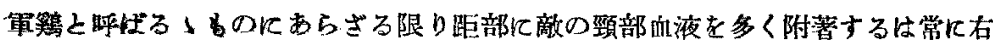

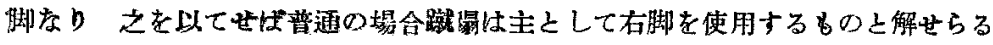
從て打瘦る亦右脚のるの大なる普连とす。

\section{VIII．運動間に於ける左台の不相稱}

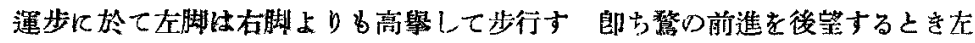

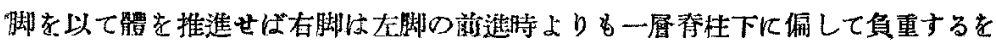

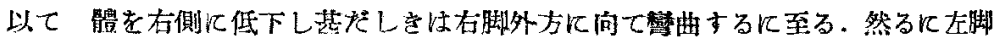

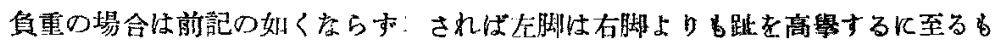

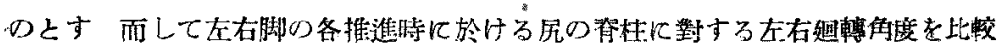
するに.右脚の推進時に於ける艽の左側轉问は左脚の場合上りに著明なり。此の

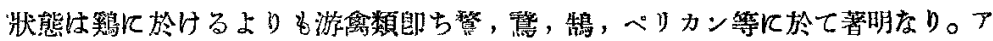
ウム,インコ, セキセイ等の攀禽類が樹枝より小舍の周圍の金網沉飛で移る時左 脚を上にし右脚老下にして止をる場合多し，又地上上り金網に攀じ上る場合在脚 を先にしヌ中途に止る上をは左脚を上にするてと晋通なり。

叉アウムが抄上を速步して前進する場合其の步調は左速步なり 郎ち左脚の運 步を速め常に左脚より前進する步調を是す。

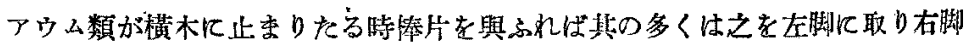
在以て負重して棒片を頻りに琶る。

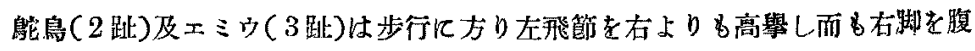
下に入れ右脚外踵に多く負重する狀熊を以て前進す。

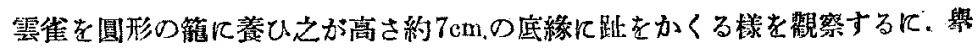

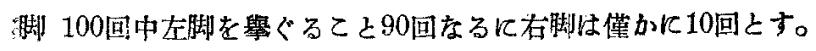

\section{IX. 總括}




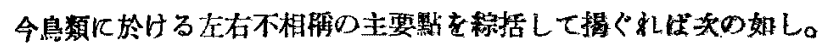

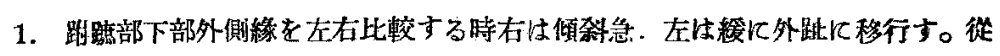
て之と外趾との成角度は左脚は右脚よりる大なり。

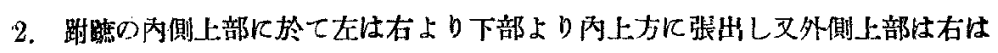

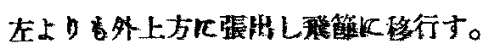

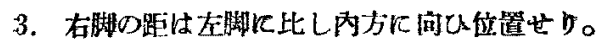

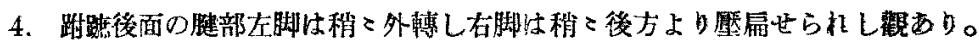

5. 後趾に於て右郝の6のは左脚に比し內方に问つて位置せり。

6. 中趾の爪に於て右脚のbのは外側急內側緩なる傾科をなする方脚のものは其 の程度幽し。

7. 趾の爪は去趾のむの橫德一般に大なり殊に中趾に於て明膫なり。

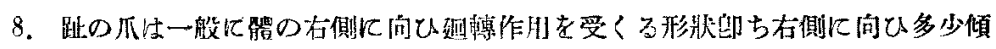
$\forall り 。$

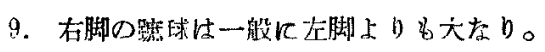

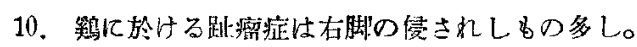

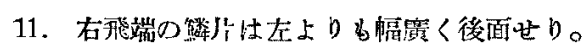

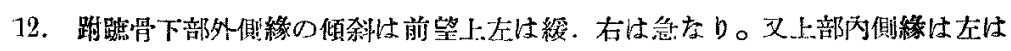

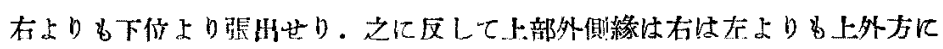
向ひ镸山せり，されば左右踓蹠骨の內外䁌緣の傾科㤌上及下部に於て夫及相 反せり。

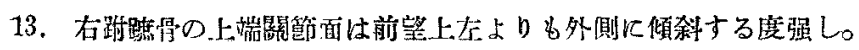

14. 跗蹠骨の上端及下端の橫徑は左は右上りも大なるもの多し。

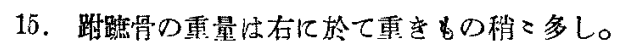

16. 踊蹠骨の外側の長さは左に热て. 叉內側の長さは右に於て稍 多し。

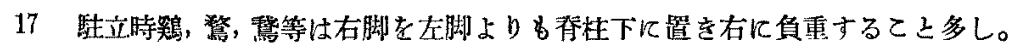

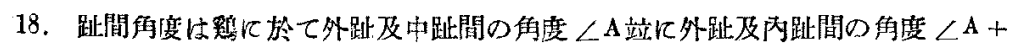

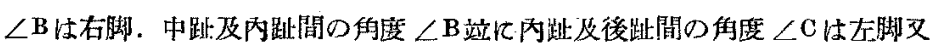
後趾及中趾の後方延長線閒角度 $\angle \mathrm{D}$ は右脚の大なる

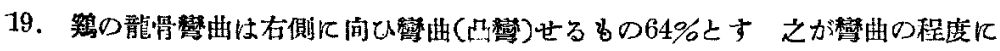


應じ同側胁骨は扇平と疗る。

20. 死鴙に於て踓蹠部下端の趾に對する運動性は右脚に於て一屡自由なり。

21. 電缹は澍爭間右四ツに組さ場合多し此の場合は左四ツに縕みたる場合よりる

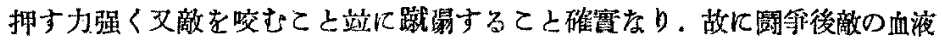
を右脚の距部に附著せるもの多し。

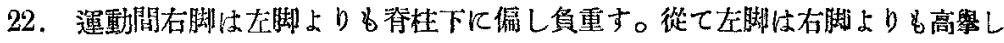

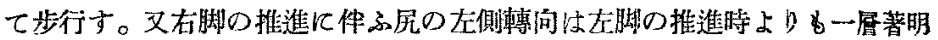
なり特に游皕類に於て明店り。

\section{X. 右利き・左利きに對する考察}

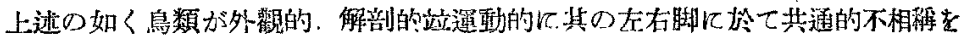

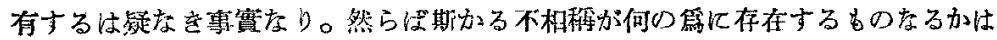
大に研筞要すべし。

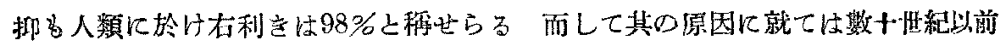

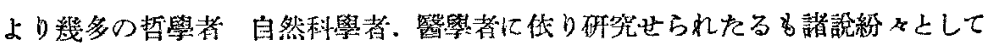

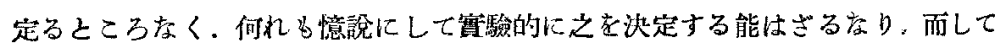
右利きは人間特有の妙㶿にして他の動物には人間に於けるが如く右利をが絕涟多

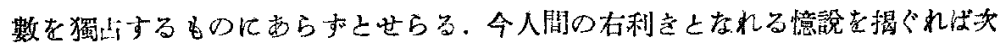
○如し。

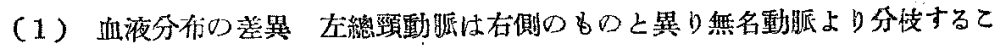
となく直接大動脈より分枝するが故に血流は左側は右側に比し盛となるさされば

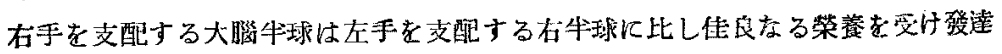
するを以て右利を孝生㕲。

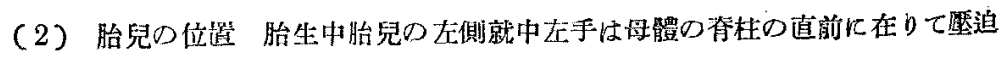

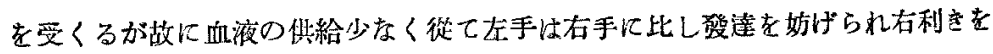
生和。

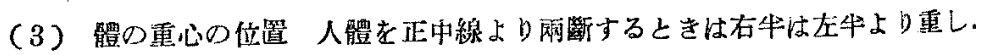
之市內㙎の分布不相稱なるによる。

（4）教化習慣による 原始人類全般は拜日数にして萬象の父唯一の神と㟤拜す 
る太陽を直面に拜する時太陽の運行する道程は彼等の右手の方面疗り。故に右手 を盆び右手を多く用しるに至れり。

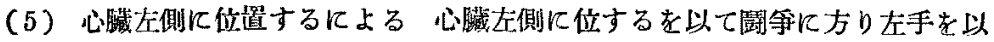
て之を保護せざるべからざる結果勢し右手を使用するの巳む度をに至る。

人間の右利をとなりる原因に就ては以上の如く諸說あるも何れも未代真置

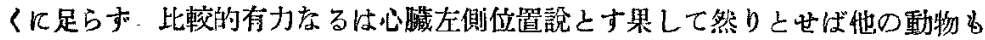
亦左側に心藏を有する限り右利きたらざるべからざるなり。然るに今日迄右利を 情萬物の露長たる人間なるが故に存すとせらる，而して人間は言語を交はすが故 几其の手足の動作形態に依らざるる右利をか左利をか子確め得るに反し動物は

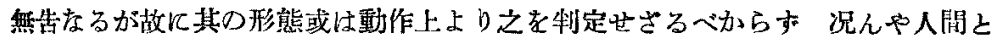
形態及渾步上極端をる相堂を有する 鳥類に對しては之が右利を 左利をの判定 は至難と云はざるべからず然れどる形態並運步上明膫疗る左右の不相程存在せ る限り本問題は解說せられ得べをると信市. 於是余は上述鳥類に於ける脚の形

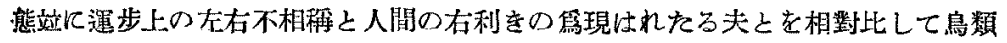
○右利宝左利を考察せんとす。

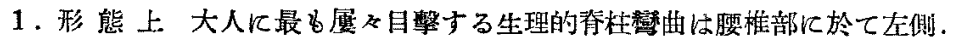

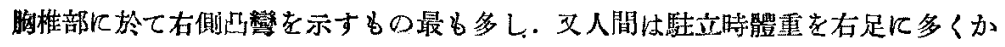
く。從て左足を前に出して休息する時間は右足を前に出して休む時間よりる無し 叉靴を等く時或は㧤く特何れも右足に負重して左足上り先にす 又坐る時は右足 失を輕く左足尖上に乘せ右足裹上に尻を置くを普通とす。又「折り數け」の號令 あれば右足を折りて右尻を地上に下ろし左滕を前方にして立つ. 又步行する時に

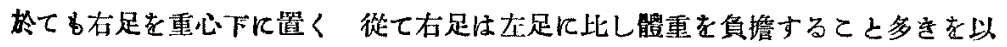
て左足上りる外例に漏重す，されば右足の第四趾及第五趾は弶曲相寄り第三趾に 间つて接著す、されば五趾端の形成する弧線は右足は左足に比し弧形を減す 又 足頸に於ける外側の形狀を左右比較する時右は左よりる凹陷强し。垖ち右の外側

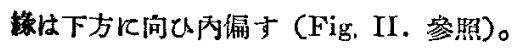

及右足は以上の如を趾の形狀を有し且坐り方をなすを以て台に比し趾間の水蝶

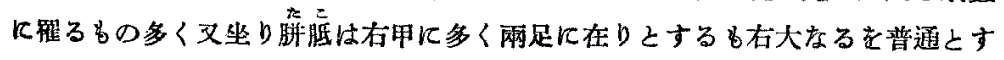
又人間の靴の磨堿は左よりも右に多く而も外側に偏せり從て長く第を慣らせる靴 
の形狀恃左は比較的變形少なを右は甲革小指部に於て張り出す：從て上方上り 之老朓むれば左は外側の底緗能く見他るに反し右は內側の底緣多く見え外側の属

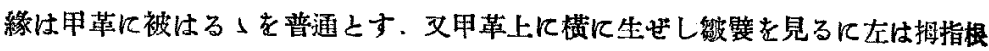

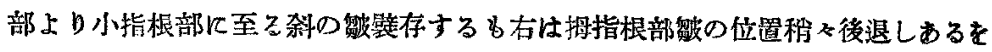

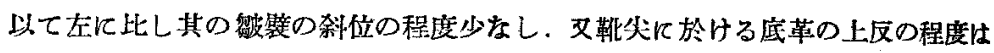
右に强く而も著しく外偏せり。左利をの者にすりては以上之相反せり。

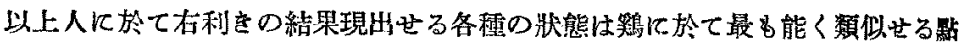
あり。郎ち左右脚に於ける躍蹠下部形態の不相稱. 跬立時右脚に多く負重すると

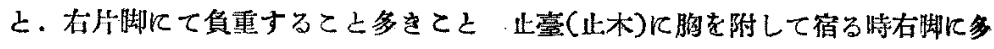

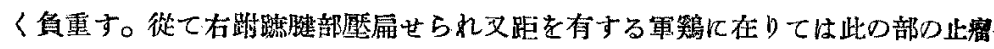

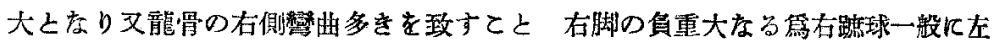

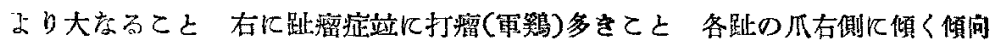

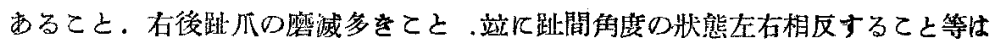
右利の人間と相通ずるとてろ赻なからす。

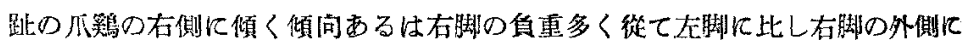

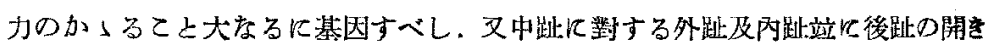

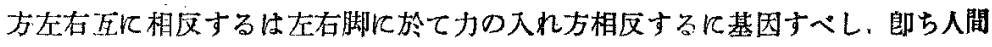
の右藏に於て甲革小指部に於て張り出すが如く右脚趾は跗蹠管を暲として少しく

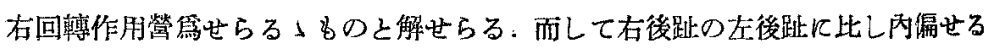

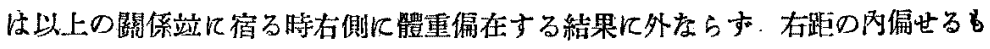
亦宿る時の右側偏重により後方より是迫せらる」に因るへし。

2、運動上人閒の步行には必ず一定の手前すり，右利壳の者は方手前を普

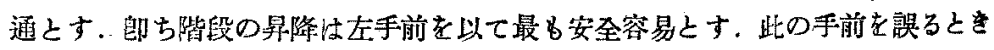
は蹉つを倒るっこと多し人は左手前得手なるが故に左足を高く舉げて前に前に

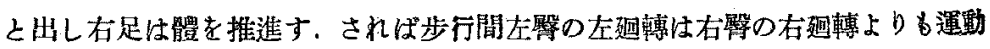
量著しく大なり 徒步敎練に於て前進は先づ左足よりし刃步調の合はざる畤踏み

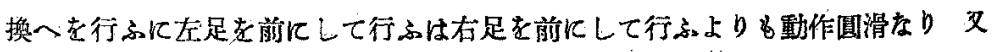
各種のメポーツに於て左迥りのコースを取れるは公間が左手前の行動を有利とせ

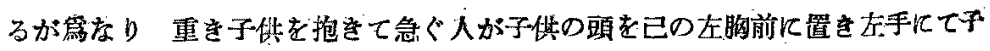


供の胴を右手にて足をから 一左肩を前にして進み行くは右利を者の右手前行進を 現はせる狀態友り。

人は頸を左右に曲ぐるに方り属曲容易なるは左側とす 鴙の休眠に方り頭を翼

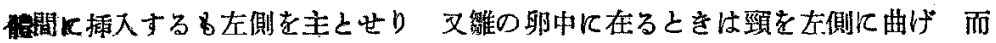

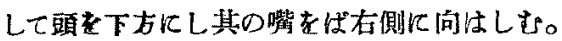

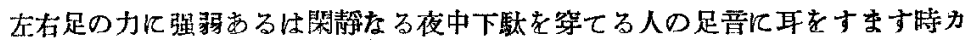

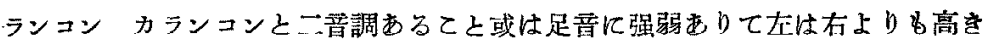

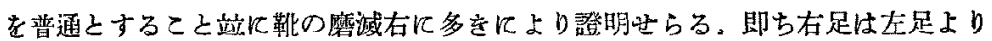

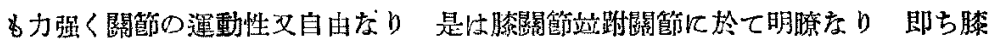

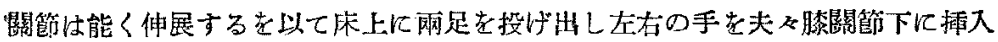

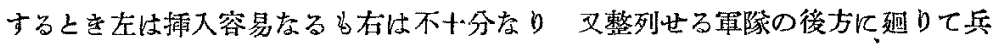

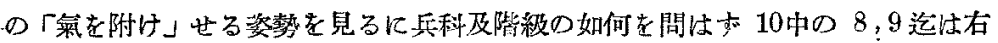
腓晹部が左腓晹部より後方に位置せるを認む，是右膝能く伸展せるが窵なり 叉 来道，角力等に於て敵之組む場合右利をの者は右足(腰)强く之に力を入れ負重す ること多し。

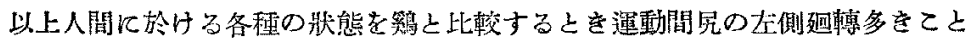

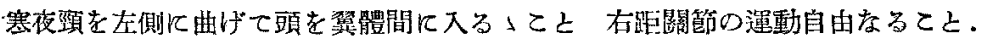
左脚を高舉し右脚を背柱下に踏み前進すること 軍鴙の闘笋に於て互に頸を組み 合す時右四ツに組むとと多く而も此の祭左四ツに組みたる場合よりも踏張り力强

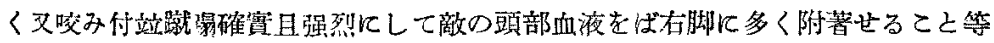
は人間の右利をと相通ぜるると解せらる。

斯く外觀的，解剖的盖運動上左右脚に於ける不相稱制然をるる悲しをことには

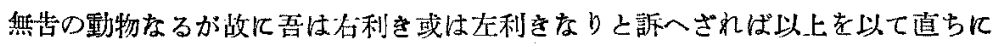

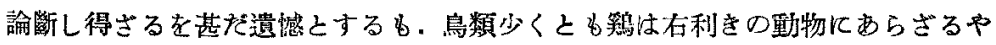

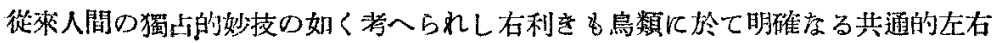
不相䄳現存せるに於ては唯獨り人間のみが前記何れかの原因により右利きに成れ りとは解し得さるところなり 况んや右利をの原因何れ是で真因と思はる」る の店に於ておや 於是余恐らく造物主は獨り人間に右利きを惠與せるにあら ナして各種動物に同柱右利をを與人をるものにあらさるやを考ふるるのなり。 


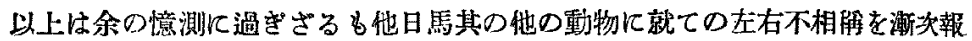
告し以て一居本憶測の過たざるを證明せんとす。

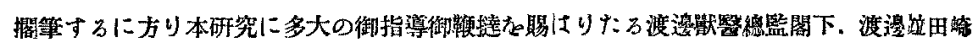

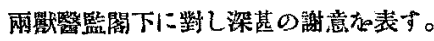




\section{松原論 文 附圖 (I)}

Fig. I. 鷄 脚 の 前“望

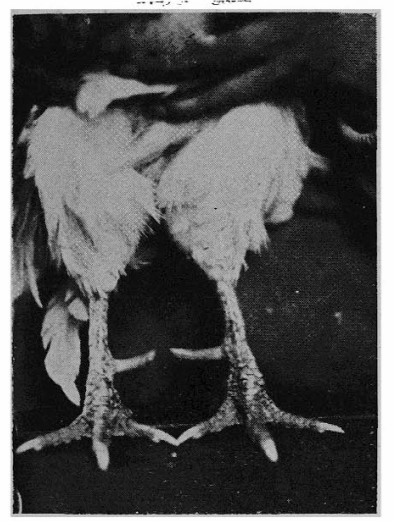

Fig. II. 人跑關箅外側角度の此較(左大)

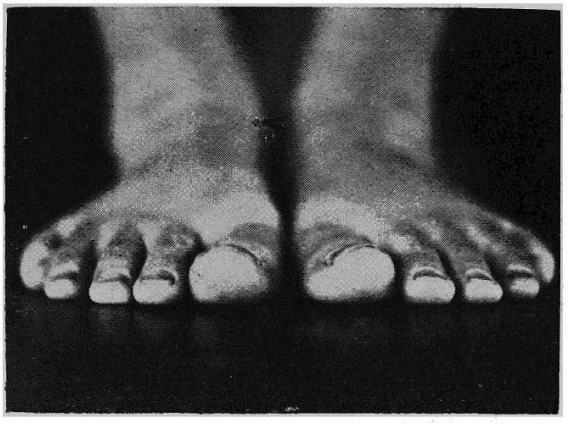

Fin. III. 默鳥 鹏 の 後望

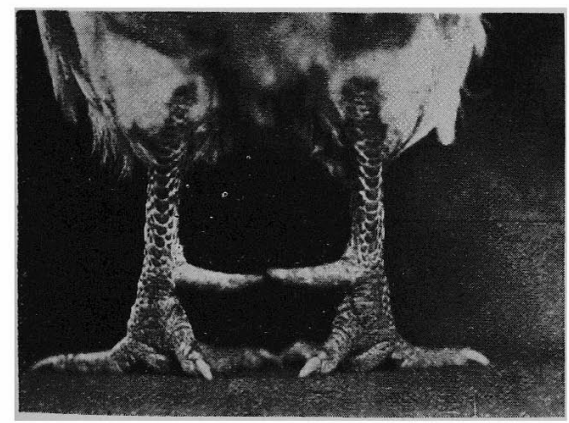

Fig. IV 雨鵢の脚前架

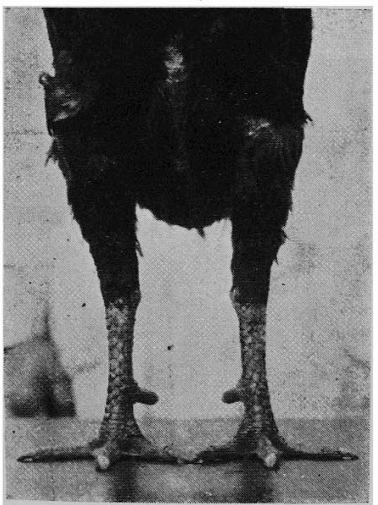




\section{松原論文附圖 (II)}

Fig, V. Fig.IV のレントゲン透視

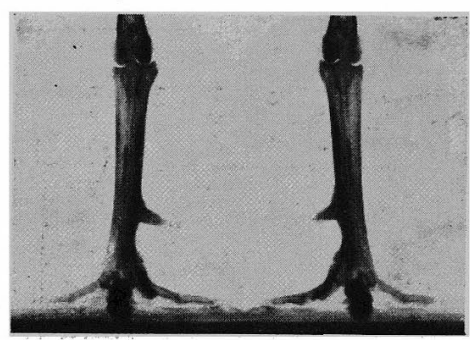

Fig. VI. 瓷 の 脚 前 望

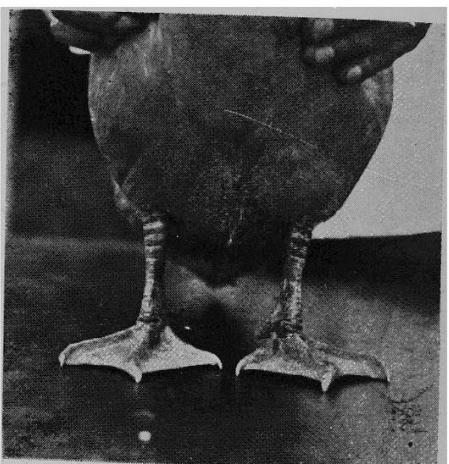

Fig. VII. Fig. VI のレントゲン透視

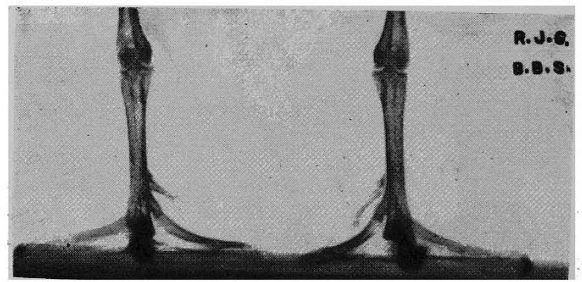

Fig. VIII，鴙の趾間角度.爪幅. 距の方向

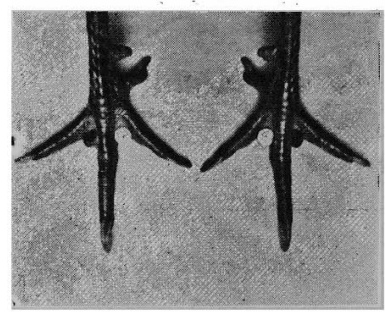




\section{松”原 論 交 附圖 (III)}

Fix. IX. 第の趾閭角度及延爪の維曲

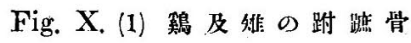

鶴

绯
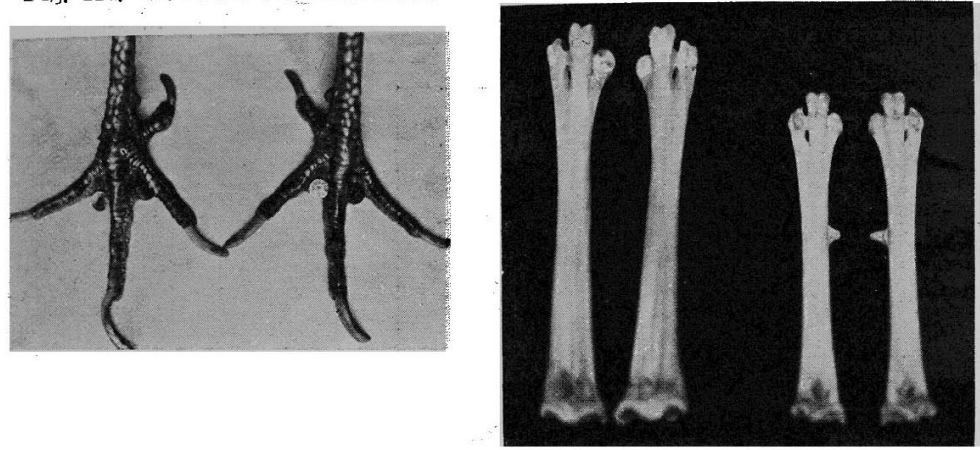

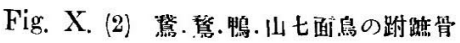
七面鳥鴨䝷登

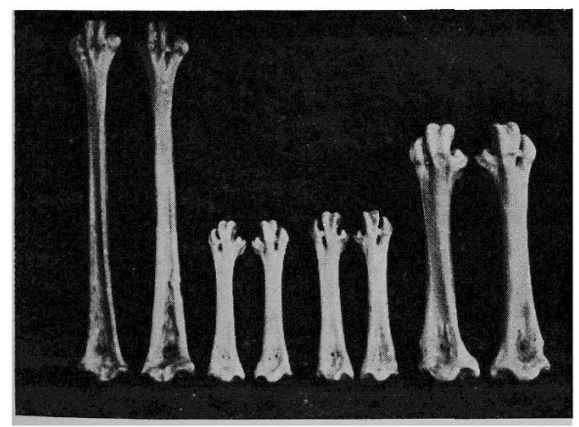

Fig. X. (3) 烏及鳩の乾摭凊

烏

酎

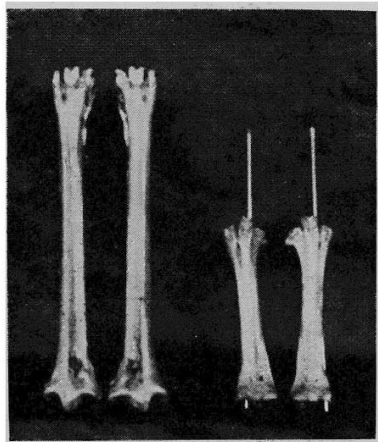




\section{松原論文附圖 (IV)}

Fig. $X$.

(4)つぐみ.ひよ うら゙ら.ひとり.かなり

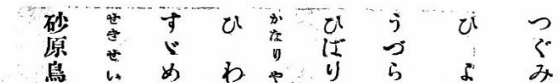

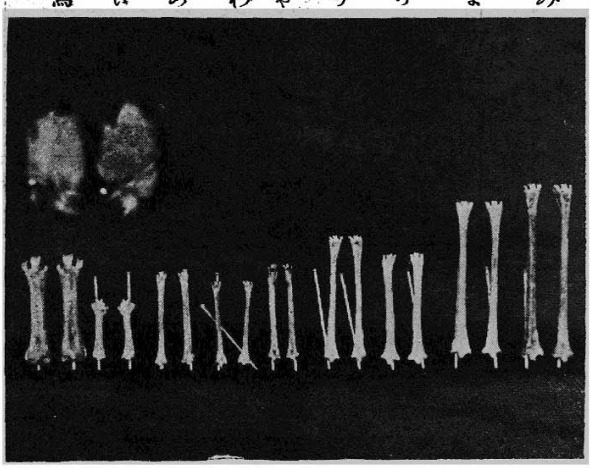

埆鳥の跗䠛骨

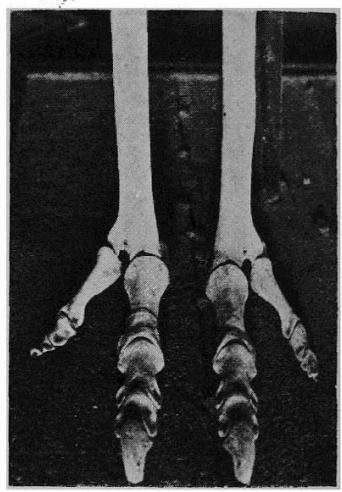

Fig. XI. 鵸龍尚の彎曲

存 彎曲

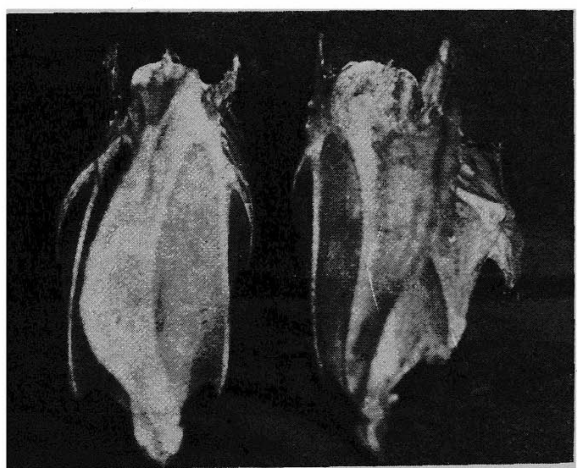

Fig. XII.

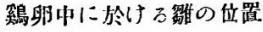

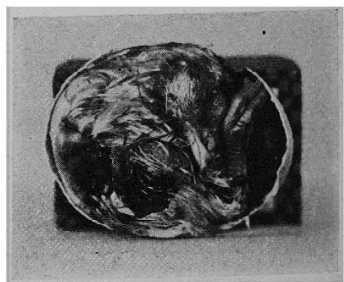

